\title{
Urban Morphology Aspects on Microclimate in a Hot and Humid Climate
}

\author{
Beta Paramita ${ }^{\mathrm{A}^{*}}$, Andreas Matzarakis ${ }^{\mathrm{B}}$ \\ Received: November 30, 2019 | Revised: December 28, 2019 | Accepted: December 30, 2019 \\ DOI: $10.5937 / g p 23-24260$
}

\begin{abstract}
Bandung, the capital of West Java province, Indonesia has experienced rapid urbanization, which has affected the urban environment, including its building density, land use, and the quality of urban living. This specific urban morphology has had a significant effect on the urban microclimate. This study was aimed at describing the urban microclimate of three different overcrowded settlements, i.e., Linggawastu (overcrowded settlement), Gerlong Girang (moderately crowded), and Pasir Impun (least crowded). The discussion will detail aspects of the masses and buildings, the distance between buildings, the height of buildings, and the availability of green open spaces to give the perspective of urban morphology toward the microclimate. Fixed weather logger in those three locations were collected over one month, meanwhile the mobile measurements to find the micro-meteorological values of air temperature ( $\mathrm{Ta})$, globe temperature (Tg), humidity $(\mathrm{RH})$, and wind speed $(\mathrm{v})$ to define the mean radiant temperature (Tmrt). The measurements provided evidence of the trend of heat trapped in densely populated settlements shown in the diurnal temperature range from Tamax and Tamin $(\Delta \mathrm{Ta})$ as only $3.2^{\circ} \mathrm{C}$. Meanwhile in Pasirimpun, which is least populated, $\Delta \mathrm{Ta}=9.5^{\circ} \mathrm{C}$. Linggawastu with building coverage ratio $(\mathrm{BCR})>96 \%$ gave the contribution of low $\mathrm{Tg}=28.3^{\circ} \mathrm{C}$, as there is less insolation penetration to the area. Thus, the PET for two densely populated areas, Linggawastu and Gerlong Girang, tends to be neutral to slightly cool. Nevertheless, this study points out the high humidity in the morning and afternoon, as well as the low air velocity, is a strong affecting factor.
\end{abstract}

Keywords: overcrowded settlement; microclimate; physiologically equivalent temperature; hot and humid climate

\section{Introduction}

Bandung, the capital of West Java province, has the largest population in Indonesia. The rapid pace of urbanization and increasing population in this metropolitan city contribute to the population density, which affects building density. The record for land settlements in Bandung occupies the largest percentage, $57 \%$, followed by industry at $20 \%$ while education services have a percentage of $2 \%$ land use. Bandung's open green area is only $7 \%$ of the total area of Bandung City (BPS Bandung, 2016). The disproportionate distribution of land use causes the concentration of urban activity at certain points, which contributes positively to building density, which is closely related to urban morphology, such as the shape and mass of buildings and the distance between buildings. The building height and the availability of green open spaces play an important role in the formation of an urban microclimate and of the urban heat island. The IPCC -5 report mentions that buildings have the greatest potential for reducing carbon emissions, compared to the other five sources of energy use: transportation, industry, agriculture, forestry, and waste (IPCC, 2014).

Meanwhile, Bandung's slum areas have experienced rapid growth, based on Ciptakarya.

\footnotetext{
A Universitas Pendidikan Indonesia

B Deutscher Wetterdienst, German Meteorological Service, Germany

* Corresponding author: Beta Paramita; e-mail: betaparamita@upi.edu
} 
In 2008, there was 202 ha and in 2013, there was 253 ha where slum areas spread over 18 districts. This area then expanded as large as 1509.5 ha in 2015 (PemkotBandung, 2015). Later came the decision for the location of the city without slums program (KOTAKU), then stated in SK Dirjen Ciptakarya No.110 / KPTS / DC / 2016 (Dirjen-Cipta Karya, 2016).

Overcrowded settlements in Indonesia are known as kampong. "The Malay word Kampong first entered Portuguese and Dutch in the 1600 s and underwent various intermediate variant spellings. The most common examples are (1) Campon/Campong and (2) Campond/Kampund (seen in some Dutch town maps for the East Indies)" (Singapurastories, 2005; Tajudeen, 2005).

Kampong Kota (Urban Kampong) is a phenomenon of growth of residential areas in big cities in Indonesia. Its unstructured existence, owing to a lack of adequate planning, leads to a gap in the quality of the disaster-prone environment. Specifically, urban kampongs with densely packed buildings have implications for the lack of air movement (ventilation) in the area, causing heat to become trapped in the material and not decompose into the air quickly. As a result, heat release occurs in the afternoon until night time, so the evening air temperature is higher than the temperature in the morning. The building density and the surface area form an urban microclimate, which significantly indicates an increase in local temperature, as well as an urban heat island effect (Paramita \& Fuku$\mathrm{da}, 2014 \mathrm{~b})$. A study on the relationship between densely populated settlements with improved microclimate found the coefficient of the building floor (FAR) has significance to the increase in temperature of the region (Paramita \& Fukuda, 2018). The study also mentioned the greater the level of closure of an area, the less the thermal comfort the area gets.

Further, studies on high-density urban villages in Kelurahan Tamansari, Bandung show the mean temperature of area radiation is higher than the Cigondewah industrial area and education area, UPI (Paramita \& Fukuda, 2014a). Those researchers also revealed that diurnal local temperature in West Bandung and North Bandung reached its maximum in the afternoon at $4 \mathrm{PM}$ and was higher than the morning temperatures. The morning and afternoon temperature difference reached $6-11{ }^{\circ} \mathrm{C}$. This indicates the urban heat island phenomenon occurred in both areas. Broadly speaking, Bandung's average temperature experienced an increasing trend of $0.8^{\circ} \mathrm{C}$ over the past 20 years (BPS Bandung, 2018).

The microclimate study will be focused on the morphology of urban kampong, specifically to the building coverage ratio (BCR), floor area ratio (FAR), and street canyon of the kampong expressed in height/canyon width $(\mathrm{H} / \mathrm{W})$. The effect of this morphological physical aspect will result in a measure of the region's microclimate covering the average radiation temperature (Tmrt) based on the temperature of the black sphere $(\mathrm{Tg})$, air temperature $(\mathrm{Ta})$, humidity $(\mathrm{RH})$, and wind velocity (v). The relationship between urban morphology and later meteorological aspects will affect the quality of the built environment based on the thermal comfort of the outdoor space expressed in PET (physiologically equivalent temperature), which describes the effect of the thermal environment on the human body.

\section{Study area}

The investigation was conducted in the city of Bandung, Indonesia. Its climate is characterized as hot and humid with high precipitation and long solar radiation intensities. The annual average relative humidity of the city is around $78 \%$. The highest air temperature is in July and August with an average maximum temperature of $29^{\circ} \mathrm{C}$. Three settlement areas were selected to evaluate the effect of urban form on the mi- croclimate: (1) Pasir Impun, (2) Linggawastu, and (3) Gerlong Girang. Pasir Impun, a suburb settlement located at $-6.89^{\circ} \mathrm{S}$ and $107.67^{\circ} \mathrm{E}$ with $695.1 \mathrm{masl}$ is in East Bandung. Linggawastu, a riverside settlement with an altitude of $727.4 \mathrm{~m}$ is located at $-6.9^{\circ} \mathrm{S}$ and $107.6^{\circ} \mathrm{E}$. Gerlong Girang, a settlement in an educational area, is located in North Bandung at 903.9 masl between $-6.86^{\circ} \mathrm{S}$ and $107.59^{\circ} \mathrm{E}$.

\section{Research method}

This study elaborates on two important aspects of urban physics, which define an environmental quality as livability, as shown in Figure 1. To evaluate the effect of urban form on the microclimate, two series of measurements were carried out. First, there was a fixed measurement to find the $\mathrm{Tg}$ and Ta that span from June 12th to July 7 th,
2017, using ESPEC ${ }^{\oplus} \mathrm{RT}_{13}$. Secondly, there was a mobile measurement on June 21st, 2017 using WEATHERmeter for six spots in one area by measuring their $\mathrm{Ta}, \mathrm{RH}$, and v. The measurements started from 6:00 a.m. to 6:00 p.m. with a ten-minute interval for each spot. Table 1 shows the technical characteristics of measurement instruments. 
Table 1. Measurement Tool Characteristic

\begin{tabular}{|c|c|c|c|}
\hline Variable & Equipment & Measurement range & Accuracy \\
\hline \multicolumn{4}{|c|}{ Recorded measurement } \\
\hline Air Temp (Ta) & Espec ${ }^{\circledR} \mathrm{RT}-12$ & $(-40 \text { to } 110)^{\circ} \mathrm{C}$ & $\begin{array}{c}\text { Avg. } \pm 0.3^{\circ} \mathrm{C} \\
\left((-20 \text { to } 80)^{\circ} \mathrm{C}\right)\end{array}$ \\
\hline Globe Temp (Tg) & Espec ${ }^{\circledR} \mathrm{RT}-12$ & $(-40 \text { to } 110)^{\circ} \mathrm{C}$ & $\begin{array}{c}\text { Avg. } \pm 0.3^{\circ} \mathrm{C} \\
\left((-20 \text { to } 80)^{\circ} \mathrm{C}\right)\end{array}$ \\
\hline \multicolumn{4}{|c|}{ Recorded measurement } \\
\hline Air Temp (Ta) & WEATHERmeter ${ }^{\circledR}$ & $(-100 \text { to } 130)^{\circ} \mathrm{C}$ & $\pm(1 \% \operatorname{rdg}+1)$ \\
\hline Humidity (RH) & WEATHERmeter ${ }^{\circledR}$ & (10 to 95$) \% \mathrm{RH}$ & $\begin{array}{c}\geq 70 \% \mathrm{RH}:+ \\
(4 \% \mathrm{rdg}+1.2 \% \mathrm{RH})\end{array}$ \\
\hline Windspeed (v) & WEATHERmeter ${ }^{\circledR}$ & (0.4 to 30.0$) \mathrm{m} \mathrm{s}^{-1}$ & $\pm 5 \%$ \\
\hline
\end{tabular}

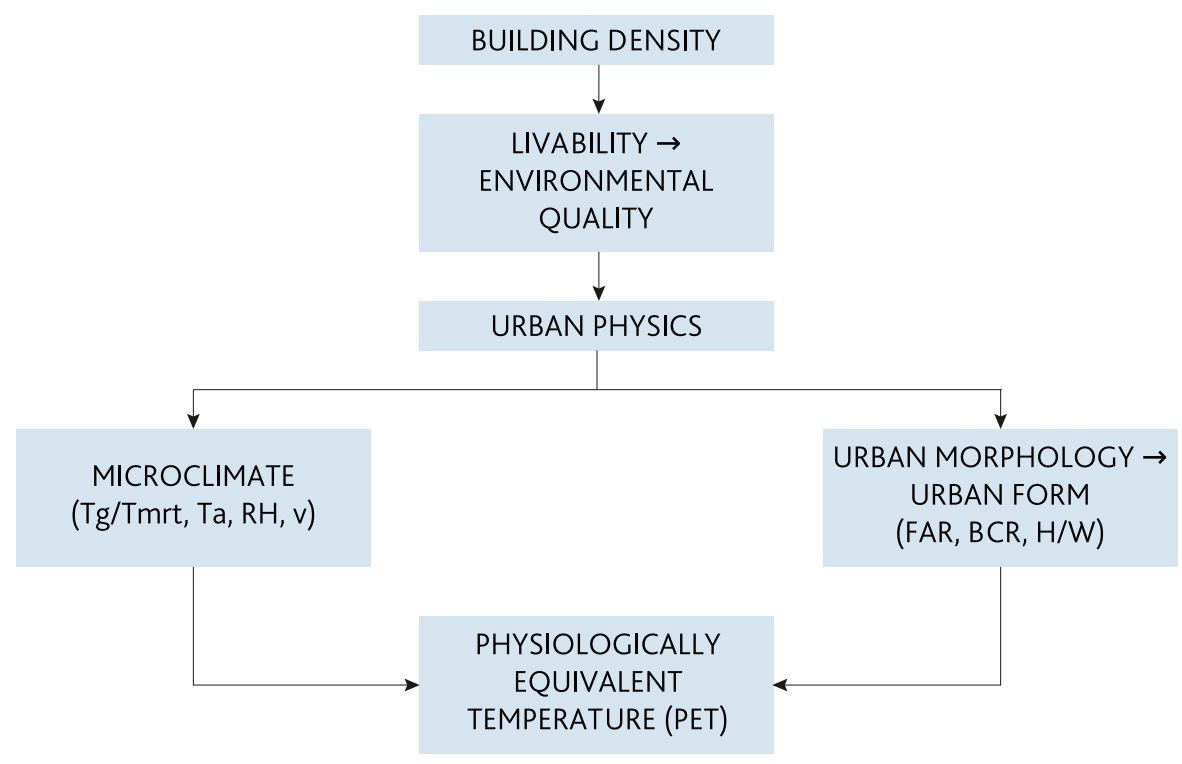

Figure 1. Research diagram

\section{Density and livability}

"By tracing the history of the origin of the Kampong as an important part of their own image, we tend to understand the kampong as an emerging settlement, not part of a road arrangement and building placement plan. The definition that takes the perspective of this 'planner' has the advantage that it includes elements that are often the triggers of state action, that is, chaos. Land placement is usually irregular in both shape and size, inter-settlement patterns tend to zig-zag, and homes are self-constructed by residents" (Khusyairi \& Rabani, 2011).

Kampong's structure, as mentioned above, is quite elusive, including its density which is difficult to measure. This density is divided into two categories: people and building density. Further, the link between density and sprawl is livability, which explains the environmental quality. This connection has been published in the Density Atlas (Lee, 2011). The connection of living quality on kampong, later explained through urban physics and outdoor thermal comfort perception. The physiologically equivalent temperature (PET) then is used to define the microclimate condition on human biometeorology.

Urban physics was first mentioned as an effect of the micro-climate on thermal comfort, health, and energy demand. It is a discipline related to branches of physics, environmental chemistry, aerodynamics, meteorology, and statistics (Moonen et al., 2012).

This paper addresses the role of urban physics in the study of microclimate, which measures globe temperature $(\mathrm{Tg})$, air temperature $(\mathrm{Ta})$, humidity $(\mathrm{RH})$, and velocity $(\mathrm{v})$, which then define the mean radiant temperature (Tmrt). Tmrt, an essential meteorological parameter, influences the thermal comfort (heat load) of humans (Chen et al., 2014a; Herrmann \& Matzarakis, 2012; Tan et al., 2013).

It is known that urban form has significant effects on the microclimate (Bajšanski et al., 2015; Milošević et al., 2017; Ongoma et al., 2016). Different combinations 
of plot ratio and site coverage will manifest in various different built forms. Studies on low-rise, high-density buildings have shown that streets with a small skyview factor often lead to increased heat-island effects in the evening owing to the trapping of long-wave radiation from the urban surface (Saehoon \& Youngry$\mathrm{el}, 2015)$. Other studies have shown that the built form and vegetation has a significant impact on the temperature variations in a hot and humid climate (Shashua-Bar et al., 2006). The densely built environment creates an very-restricted sky view factor, which then impacts the mean radiant temperature across different outdoor spaces. In hot and humid regions, a large sky-view factor is preferable for cooling open spaces (Lai et al., 2017). The distance between building significantly impacts the building façade's surface temperatures. However, wind flow can remove the heat within the urban morphology (Allegrini et al., 2015). A previous study on densely built environments in Bandung, Indonesia shows that the regression between building coverage and mean radiant temperature are connected with R2 = 0.82 (Paramita \& Fukuda, 2014a).

Lying near the equator, Bandung city is facing a long period of insolation. The improvement of urban microclimates in achieving outdoor thermal comfort simply involves altering surface temperatures of the surroundings that cover urban areas. Based on the above description of outdoor thermal perception, it is clear that microclimates play an important role in creating specific atmospheric conditions that impact thermal comfort. According to Fanger, and updated by Moran (Epstein \&
Moran, 2006; Povl Ole Fanger, 1972), seven factors significantly determine the human thermal environment and an individual's thermal comfort. These factors are divided into environmental factors, which are $\mathrm{Ta}, \mathrm{Tg}, \mathrm{v}$ and $\mathrm{RH}$, and human behavioral factors, which are metabolic rate, clothing insulation, and moisture permeability.

Later, the living quality of the urban environment was referred to PET, a thermal index derived from the human energy balance. The PET classification will be used for Taiwan's hot and humid climate (Lin et al., 2010). The annual average temperature in Bandung is $23.4^{\circ} \mathrm{C}$. Meanwhile, previous study showed that neutral temperature (Tn) in Bandung is $24.7^{\circ} \mathrm{C}$ where the range of thermal comfort ( $\mathrm{Tcr}$ ) is $23-26.5^{\circ} \mathrm{C}$ (Karyono, 2008). Thus, on average, the perception of PET normally will be slightly cool.

The high outdoor thermal comfort can only be achieved when the building group design strategies are well applied. Therefore, the idea of assessing overcrowded settlements regarding their microclimate will improve living quality. Despite several thermal stress indices, especially for outdoor conditions, this paper uses PET based on the energy balance of the human body. The PET can make estimates using the free available RayMan model (Chen et al., 2014b; Fröhlich \& Matzarakis, 2013; Gulyas et al., 2006; Herrmann \& Matzarakis, 2012; Matzarakis et al., 2007; Milošević et al., 2016).

The PET calculation for Pasir Impun is shown in Table 5, Linggawastu in Table 6, and Gerlong Girang in Table 7.

\section{Results and data analysis}

\section{Pasir Impun}

Figure 2 shows the diurnal of Tg and Ta characteristics from the fixed measurement within one month. It was recorded as $\mathrm{Ta}_{\max }=30.2{ }^{\circ} \mathrm{C}, \mathrm{Ta}_{\min }=20.7^{\circ} \mathrm{C}$. The highest Ta was shown in the morning from o8:00-11:00 am. Meanwhile, Figure 3 shows the diurnal temperature from the mobile measurement, where the lowest Ta was $20.7^{\circ} \mathrm{C}$. Figure shows the highest $\mathrm{Ta}, 34.0^{\circ} \mathrm{C}$, was recorded at 13:50 in spot F. Meanwhile, the highest $\mathrm{RH}$ has recorded at $06: 00$ in plot E, as much as $83 \%$. All spots had similar microclimate characteristics, where the temperature rose from 06:00 to 13:00 and then gradually decreased until the sun set. Humidity data in the morning (06:00 to 07:00 am) also showed the highest value. Nevertheless, the afternoon temperature was still higher than the morning temperatures. The average temperature from spot A until $\mathrm{F}$ was also higher than Bandung's average July temperature, which is $25.7^{\circ} \mathrm{C}$. The average temperatures for spots A to $\mathrm{F}$ were $28.4{ }^{\circ} \mathrm{C}, 28.7^{\circ} \mathrm{C}, 29.5^{\circ} \mathrm{C}, 29.7^{\circ} \mathrm{C}$, $29.9^{\circ} \mathrm{C}$ and $30.2{ }^{\circ} \mathrm{C}$. Compared to other settlement areas, Pasir Impun recorded the longest diurnal temperature range between $\operatorname{Tmax}$ and $\mathrm{Tmin}$, i.e., $9.5^{\circ} \mathrm{C}$.

Table 2 explains the density of the buildings for each measurement spot. Spot $\mathrm{E}$ has shown its density with the highest FAR $=4$ but low coverage with BCR $=38 \%$. Meanwhile, spot $\mathrm{B}$ has shown the largest coverage with BCR. 


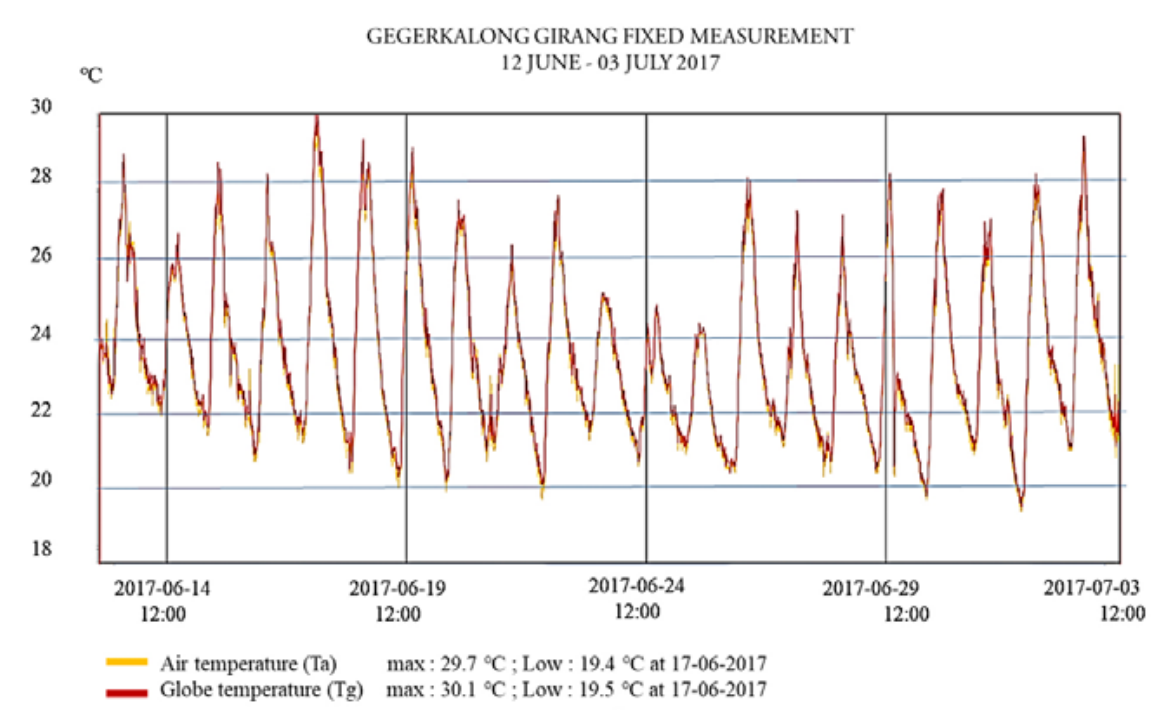

Figure 2. Diurnal Temperature from Fixed Measurement
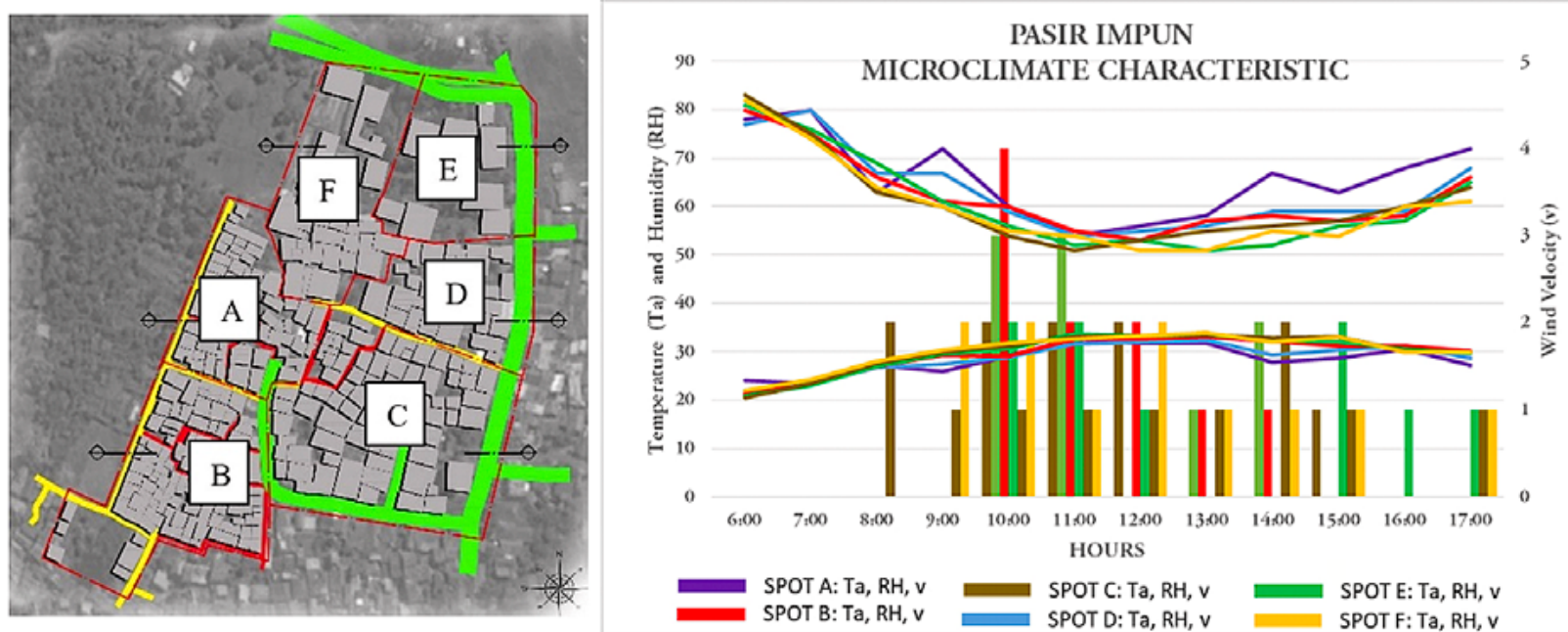

Figure 3. Measurement Spot and Microclimate characteristics in Pasir Impun

Table 2. Pasir Impun Urban Form Characteristics

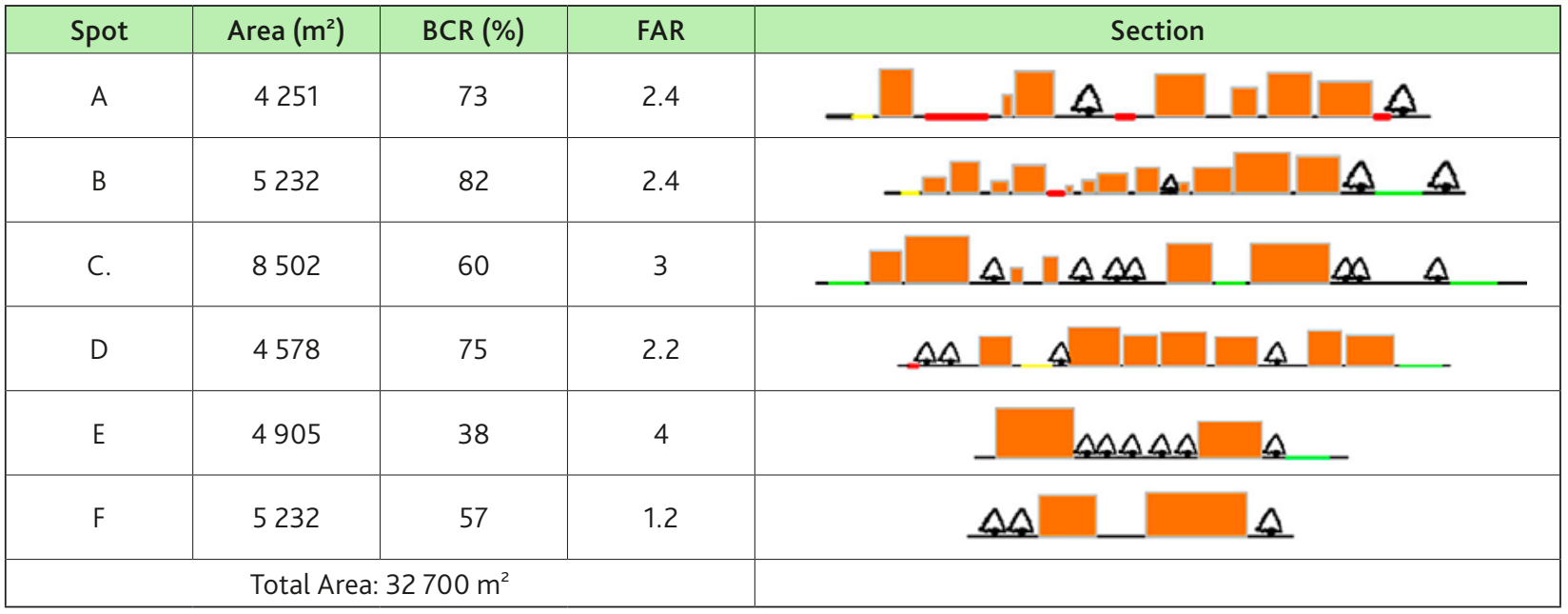




\section{Linggawastu}

Figure 4 shows the diurnal of $\mathrm{Tg}$ and $\mathrm{Ta}$ within one month of Linggawastu from fixed measurements. The highest $\mathrm{Tg}=28.6{ }^{\circ} \mathrm{C}$; the lowest $\mathrm{Tg}=24.5^{\circ} \mathrm{C}$. Meanwhile, the highest $\mathrm{Ta}=27.9{ }^{\circ} \mathrm{C}$ and the lowest $\mathrm{Ta}=$ $24.7^{\circ} \mathrm{C}$. Thus, the highest diurnal temperature range was only $3.2^{\circ} \mathrm{C}$.

The fixed measurement was apparently different from mobile measurement. The fixed measurement shows Tamax in the afternoon from 14:00-18:00 while Tamax from the mobile measurement occurred in the morning. Figure 5 shows the highest Ta in Linggawastu was $35.2{ }^{\circ} \mathrm{C}$ at 10:20 am in spot B. Meanwhile the highest humidity occurred at 06:50 as much as $92 \%$ at spot $\mathrm{F}$. The humidity value in this area was the highest compared to two other settlements. The temperature average for each spot, $\mathrm{A}$ to $\mathrm{F}$, was $29.5^{\circ} \mathrm{C} ; 30.3^{\circ} \mathrm{C}$; $29.8^{\circ} \mathrm{C} ; 29.8^{\circ} \mathrm{C} ; 29.6^{\circ} \mathrm{C} ; 29.7^{\circ} \mathrm{C}$; and $29.6{ }^{\circ} \mathrm{C}$. The longest diurnal temperature range between Tamax and Tamin in Linggawastu was recorded as $6^{\circ} \mathrm{C}$. Table 3 describes the urban form characteristics. The BCR in this area was 96.3 to $100 \%$. It is considered the largest coverage area, compared to Pasir Impun and Gerlong Girang. The overcrowded building density was also signed by its low floor area ratio (FAR), which was only 2.3 .

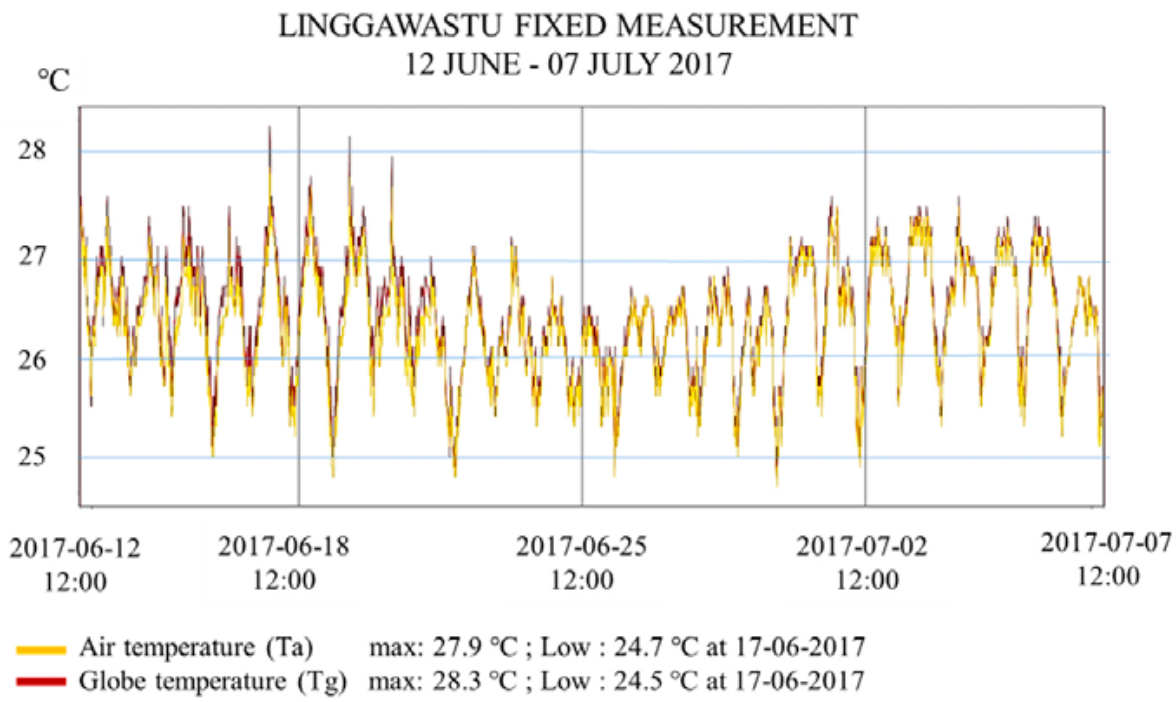

Figure 4. Linggawastu Fixed Measurement
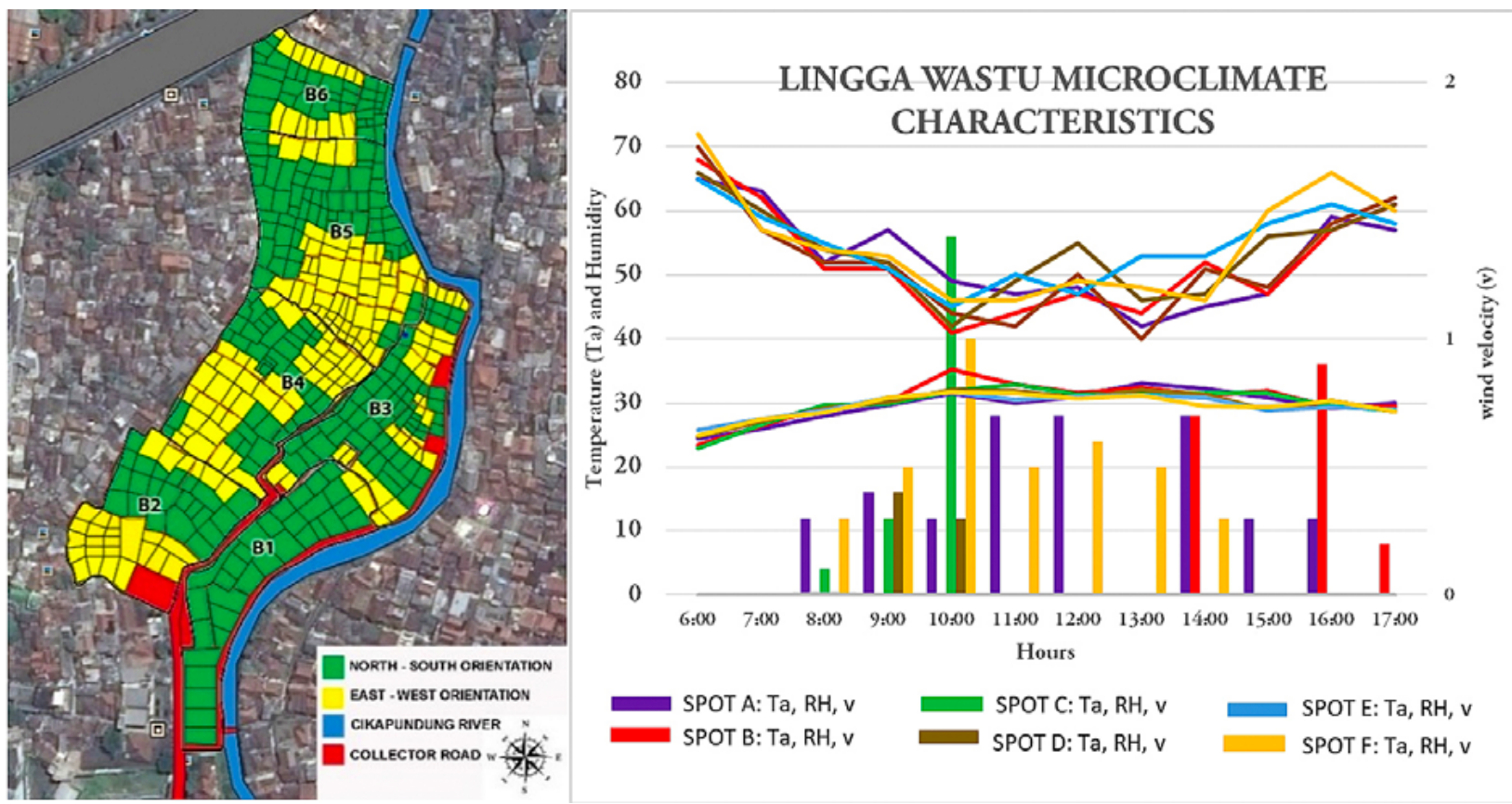

Figure 5. Measurement Spot and Microclimate characteristics in Lingga Wastu 
Table 3. Urban Form Characteristics of Lingga Wastu

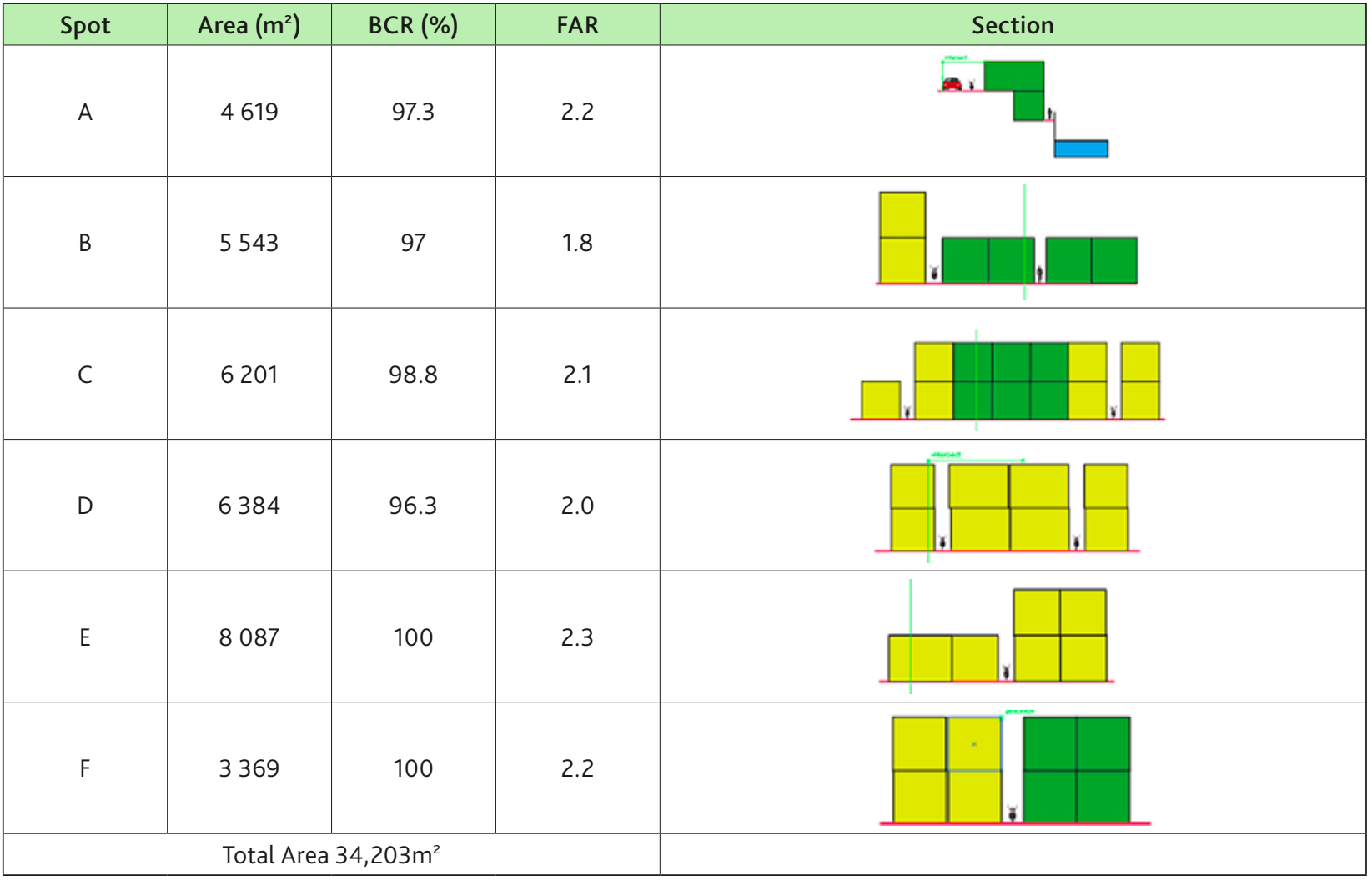

\section{Gerlong Girang}

The characteristic of diurnal $\mathrm{Ta}$ and $\mathrm{Tg}$ within one month is shown in Figure 5. There is no significant difference in $\mathrm{Ta}$ or $\mathrm{Tg}$. Solar radiation seems to have no effect on heating the outdoor temperature. This area has a BCR of more than $85 \%$, which means there is no large area of open space for insolation penetration. Figure 6 demonstrates the highest Ta in Gerlong Girang occurred at 13:10 pm in spot B with $32.6^{\circ} \mathrm{C}$. Unlike other settlement areas, where the humidity was recorded over $80 \%$, the highest humidity occurred in spot $\mathrm{D}$ at $77 \%$. All spots had similar microclimate characteristics: the temperature rose from 06:00 to 14:00 and then gradually decreased until the sun set. Similar to the other two settlement areas, the afternoon temperature in Gerlong Girang was higher than the morning temperatures, which also indicates the UHI phenomenon. The longest diurnal temperature range between Tmax and

Gegerkalong Girang Fixed Measurement

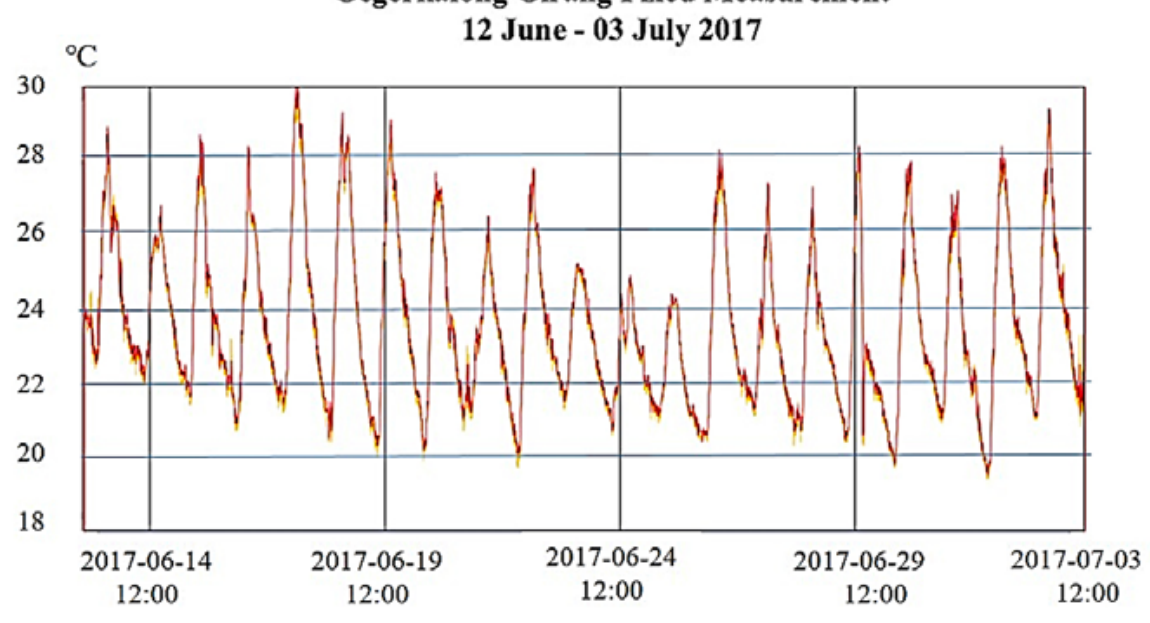

- Air temperature (Ta) $\max : 29.7^{\circ} \mathrm{C}$; Low : $19.4^{\circ} \mathrm{C}$ at $17-06-2017$

- Globe temperature $(\mathrm{Tg}) \quad \max : 30.1{ }^{\circ} \mathrm{C}$; Low : $19.5^{\circ} \mathrm{C}$ at $17-06-2017$

Figure 6. Gerlong Girang Fixed Measurement 

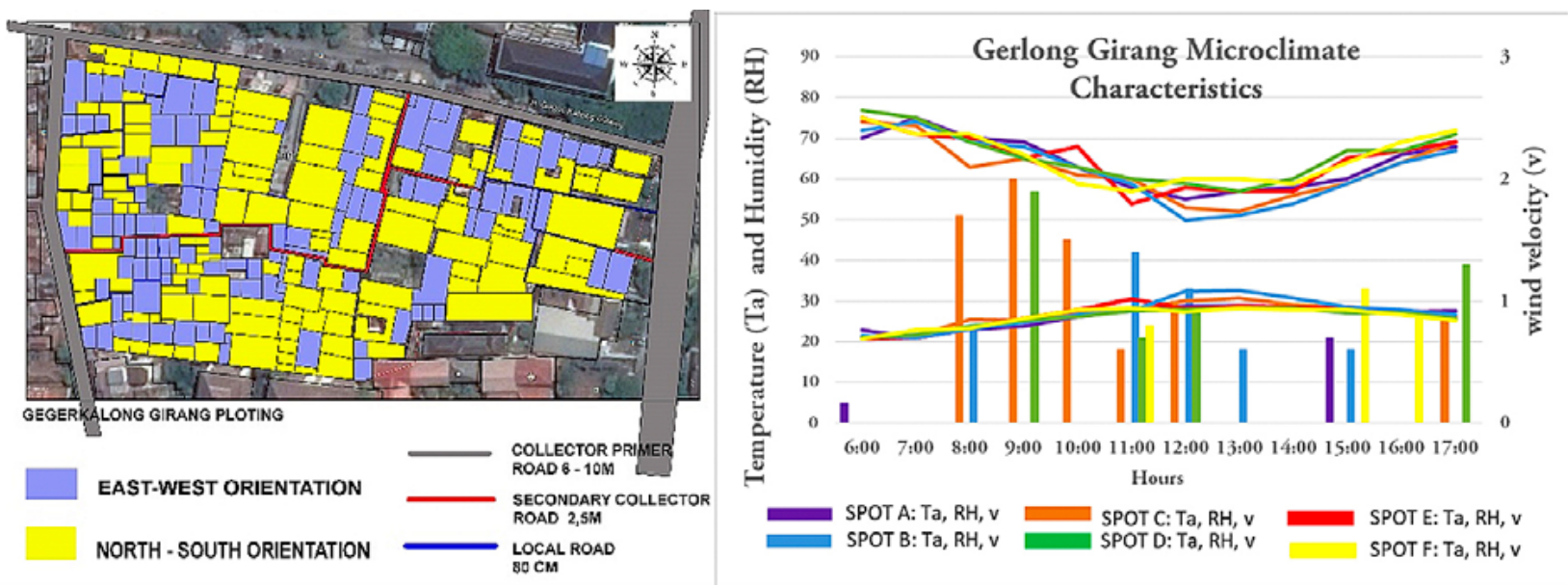

Figure 7. Measurement Spot and Microclimate characteristics in Gerlong Girang

Tmin in Gerlong Girang was the lowest compared to the other two settlement areas, i.e., $5.2^{\circ} \mathrm{C}$.

Meanwhile, Table 4 shows the similarity of urban form characteristics between Linggawastu and Gegerkalong Girang. The overcrowded building den- sity is signed with high BCR and low FAR. The highest $\mathrm{BCR}=98 \%$ and the highest FAR $=\mathbf{2 . 3}$.

Later, based on those three location measurements, it is found that PET for each of them as shown at table 5,6 and 7 .

Table 4. Urban Form Characteristics of Gerlong Girang

\begin{tabular}{|c|c|c|c|c|}
\hline Spot & Area $\left(\mathrm{m}^{2}\right)$ & BCR (\%) & FAR & Urban form \\
\hline A & 5826 & 98 & 2.0 & \\
\hline B & 6312 & 98 & 2.0 & \\
\hline C & 4370 & 88 & 2.2 & \\
\hline D & 3770 & 83 & 2.3 & \\
\hline$E$ & 7276 & 88 & 2.3 & \\
\hline $\mathrm{F}$ & 4960 & 86 & 2.3 & \\
\hline \multicolumn{4}{|c|}{ Total area $28,144 \mathrm{~m}^{2}$} & \\
\hline
\end{tabular}


Table 5. PET Pasir Impun

\begin{tabular}{|l|l|l|l|l|l|l|l|}
\hline & Tg & RH & $\mathbf{v}$ & Ta & Tmrt & PET & $\begin{array}{l}\text { Thermal } \\
\text { perception }\end{array}$ \\
\hline $6: 00$ & 21.8 & 80 & 0.0 & 28.1 & 21.8 & 25.9 & neutral \\
\hline $7: 00$ & 23.5 & 77 & 0.0 & 26.9 & 23.5 & 26.3 & neutral \\
\hline $8: 00$ & 27.4 & 65 & 0.3 & 26.6 & 28.3 & 27.2 & neutral \\
\hline $9: 00$ & 28.8 & 64 & 0.5 & 26.6 & 32.0 & 28.3 & neutral \\
\hline $10: 00$ & 30.2 & 57 & 2.3 & 25.0 & 47.6 & 29.4 & neutral \\
\hline $11: 00$ & 32.8 & 53 & 1.8 & 24.6 & 55.4 & 33.2 & Slightly warm \\
\hline $12: 00$ & 32.8 & 54 & 1.3 & 24.2 & 52.6 & 33.1 & Slightly warm \\
\hline $13: 00$ & 33.1 & 55 & 0.7 & 23.9 & 48.0 & 33.1 & Slightly warm \\
\hline $14: 00$ & 31.2 & 58 & 1.0 & 23.7 & 46.5 & 31.0 & Slightly warm \\
\hline $15: 00$ & 31.5 & 58 & 0.8 & 23.5 & 45.8 & 31.3 & Slightly warm \\
\hline $16: 00$ & 30.7 & 60 & 0.2 & 23.4 & 36.7 & 29.9 & neutral \\
\hline $17: 00$ & 29.3 & 66 & 0.4 & 23.1 & 37.0 & 28.7 & neutral \\
\hline
\end{tabular}

Table 6. PET Linggawastu

\begin{tabular}{|l|c|c|c|c|c|c|l|}
\hline & Tg & RH & $\mathbf{v}$ & Ta & tmrt & PET & $\begin{array}{l}\text { Thermal } \\
\text { perception }\end{array}$ \\
\hline $6: 00$ & 24.4 & 88 & 0.0 & 27.2 & 24.4 & 27.0 & Neutral \\
\hline $7: 00$ & 26.9 & 80 & 0.0 & 27.1 & 26.9 & 28.3 & Neutral \\
\hline $8: 00$ & 28.9 & 73 & 0.2 & 27.3 & 30.3 & 30.2 & Neutral \\
\hline $9: 00$ & 30.2 & 73 & 0.3 & 27.7 & 32.9 & 30.2 & Neutral \\
\hline $10: 00$ & 32.3 & 65 & 0.5 & 27.4 & 39.1 & 32.3 & slighty warm \\
\hline $11: 00$ & 31.6 & 66 & 0.2 & 27.3 & 35.1 & 31.4 & slighty warm \\
\hline $12: 00$ & 31.1 & 69 & 0.2 & 27.1 & 34.4 & 31.0 & slighty warm \\
\hline $13: 00$ & 31.9 & 66 & 0.1 & 27.1 & 34.5 & 31.5 & slighty warm \\
\hline $14: 00$ & 31.4 & 69 & 0.3 & 26.8 & 36.2 & 31.3 & slighty warm \\
\hline $15: 00$ & 30.3 & 73 & 0.1 & 26.6 & 32.3 & 30.2 & Neutral \\
\hline $16: 00$ & 29.7 & 80 & 0.2 & 26 & 32.8 & 29.6 & Neutral \\
\hline $17: 00$ & 29.1 & 80 & 0.0 & 26.5 & 29.1 & 29.3 & Neutral \\
\hline
\end{tabular}

Table 7. PET Gerlong Girang

\begin{tabular}{|l|l|l|l|l|l|l|l|}
\hline & Tg & RH & $\mathbf{v}$ & Tg & Tmrt & PET & $\begin{array}{l}\text { Thermal } \\
\text { Perception }\end{array}$ \\
\hline $6: 00$ & 21.4 & 74 & 0.0 & 26.3 & 21.4 & 24.9 & slighty cool \\
\hline $7: 00$ & 21.4 & 73 & 0.0 & 26.1 & 21.4 & 24.8 & slighty cool \\
\hline $8: 00$ & 23.4 & 69 & 0.4 & 25.3 & 20.8 & 22.7 & slighty cool \\
\hline $9: 00$ & 25.0 & 66 & 0.7 & 24.3 & 26.3 & 23.6 & slighty cool \\
\hline $10: 00$ & 26.9 & 63 & 0.3 & 24.1 & 30.0 & 26.4 & neutral \\
\hline $11: 00$ & 28.3 & 58 & 0.6 & 23.9 & 35.4 & 27.5 & neutral \\
\hline $12: 00$ & 29.5 & 56 & 0.6 & 23.7 & 38.6 & 28.9 & neutral \\
\hline $13: 00$ & 29.9 & 56 & 0.1 & 23.5 & 33.4 & 28.9 & neutral \\
\hline $14: 00$ & 29.2 & 57 & 0.0 & 23.2 & 29.2 & 27.9 & neutral \\
\hline $15: 00$ & 28.1 & 62 & 0.4 & 22.6 & 35.0 & 27.3 & neutral \\
\hline $16: 00$ & 27.4 & 66 & 0.2 & 22.7 & 31.4 & 26.8 & neutral \\
\hline $17: 00$ & 26.2 & 69 & 0.20 & 22.1 & 29.7 & 25.8 & neutral \\
\hline
\end{tabular}




\section{Discussion}

Studies on these three areas provide an overview of urban forms that affect microclimate, which then affect the perception of thermal comfort. The annual average temperature in Bandung of $23.7^{\circ} \mathrm{C}$ generally offers "slightly cool" perception of thermal comfort. However, in this study, we found that only Gerlong Girang offers that perception. Two other study areas, Pasir Impun and Linggawastu, tend to offer "neutral" and "slightly warm" thermal perception. The geographical location somehow delivers significant initial air temperature. Gerlong Girang, with an altitude of 907 masl, gets the benefit of low diurnal air temperature of $26.4{ }^{\circ} \mathrm{C}$. Pasir Impun and Linggawastu, with altitudes 727 and 695 masl, have relatively the same diurnal temperature of $29.3^{\circ} \mathrm{C}$ and $29.8^{\circ} \mathrm{C}$, respectively. The low index thermal perception is also influenced by the building coverage in Gerlong Girang, which is 83$98 \%$, as well as FAR 2.3, which means a lower sky view factor (SVF) blocked the solar radiation.

The less building density in Pasir Impun tends to generate a wind velocity that is higher than that in the other two areas, but somehow generates the penetration of solar radiation into open space. Overcrowded settlements, like Linggawastu with $\mathrm{BCR}=96-$ $100 \%$, block the urban ventilation and leaves the heat trapped, it shows with the small differences of diurnal temperature morning and afternoon that is only $0.7^{\circ} \mathrm{C}$.

This study then emphasizes the previous studies that urban form significantly influences the microclimate. The same tendencies were found as in Saehoon and Youngryel's work in 2017, where a small sky view factor in the low-rise high-density urban form traps the long-wave radiation from the urban surface. Pasir Impun, with low BCR, provides the availability of wind flow within urban structures. Nevertheless, in tropical zones with longer sun exposure, the more open space, the more insolation will be intruded in the area. This means globe radiation will be higher, which then impacts the mean radiant temperature and thermal perception. This is different from the study by Allegrini, Dorer, and Carmiliet in 2015 for the climate of Zürich (Switzerland), in which they stated that wind flow can remove the heat within the urban morphology. Somehow, this study is linear with the study in Singapore (Lai, Maing and Ng, 2017) that densely built form restricts the sky view factor then affects the mean radiant temperature across different outdoor spaces. This study is similar because it is done in a hot and humid climatic region.

The perception of outdoor thermal comfort in the three areas has a similar diurnal range of neutral per- ception, of $2.5{ }^{\circ} \mathrm{C}-3{ }^{\circ} \mathrm{C}$. Pasir Impun with less building coverage offers "neutral" perception in the range of $25.9{ }^{\circ} \mathrm{C}-29.9{ }^{\circ} \mathrm{C}$. Linggawastu, with overcrowded buildings, offers "neutral" perception in the range of $27{ }^{\circ} \mathrm{C}-30{ }^{\circ} \mathrm{C}$. Meanwhile, Gerlong Girang, in the highest geographical location offers "neutral" perception in the range of $26.4{ }^{\circ} \mathrm{C}-28.9^{\circ} \mathrm{C}$. Those studies are slightly different from the PET study in Colombo, Sri Lanka (Johansson \& Emmanuel, 2006) where the outdoor thermal comfort was found in the range of $27.5{ }^{\circ} \mathrm{C}-32.5^{\circ} \mathrm{C}$. Its diurnal range was $5{ }^{\circ} \mathrm{C}$ with the range of humidity $50 \%-75 \%$ at $32.5^{\circ} \mathrm{C}$ and $50 \%-85 \%$ at $27.5{ }^{\circ} \mathrm{C}$. In the other study, the range of "neutral" perception in Singapore occurred at $28.7^{\circ} \mathrm{C}$ but was preferred at $26.5^{\circ} \mathrm{C}$, where the acceptability of thermal comfort state was $26.3^{\circ} \mathrm{C}-31.7^{\circ} \mathrm{C}$ (Yang et al., 2013), which was slightly higher than the condition in Bandung but lower than in Colombo. The deeper canyon with compact $\mathrm{H} / \mathrm{W}$ on urban form can provide preferable outdoor thermal comfort than a dispersed urban form (Emmanuel \& Johansson, 2006). Anyhow, in the case of overcrowded settlement, the compact urban form has a significant influence on the rising humidity in the morning. Linggawastu with BCR nearly $100 \%$ and FAR 2.3 gathers the humidity in the morning from $06.00-09.00$, as much as $73 \%-88 \%$. This condition is similar in Dhaka, Bangladesh, which has semiclosed space that restricts air movement but provides shading, which is more preferable during the hottest period of the day (Ahmed, 2003). The perception of outdoor thermal comfort in Malaysia also confirmed the value of PET in the selected shaded outdoor spaces was higher than the comfort range defined for tropical climates. This value was more than $30^{\circ} \mathrm{C}$ (Makaremi et al., 2012). Thus, it is recommended that a mixture of high-rise towers and lower buildings can create uneven fabric, which then increases air movement in a warm climate (Evans \& De Schiller, 1996; Fanger \& Toftum, 2002). The perception of outdoor thermal comfort is also influenced by the sky view factor. The study by National Formosa University (NFU), Taiwan shows that sky view factor (SVF) significantly affects the outdoor thermal environment. There are six different SVFs in the range from 0.04 (highly shaded) until 0.808 (barely shaded) that give the perception of hot discomfort index with PET $>30^{\circ} \mathrm{C}$. Meanwhile, the discomfort index with PET is $<26^{\circ} \mathrm{C}$.

It was also found that the median shading level with SVF 0,129 contributes to the longest thermal comfort (Lin et al., 2010). Another study in Taiwan collected 505 effective questionnaires between April 15, 2007, and February 2, 2008. The thermal comfort range of 
respondents was $21.3-28.5^{\circ} \mathrm{C}$ PET, significantly higher than that in a study conducted in Central and Western Europe $\left(18-23{ }^{\circ} \mathrm{C}\right.$ PET), where the preferred temperature in the hot season was $24.5^{\circ} \mathrm{C}$ (Lin, 2009).

Those studies in Colombo, Singapore, Dhaka, Malaysia, and Taiwan within hot and humid climates give an understanding that the perception of the thermal environment cannot be explained by individual climate parameters. It won't be simply described by microclimate conditions.

The previous measurement in the same area, $\mathrm{Ta}$ mansari, which was completed in 2013, shows a different value for air temperature. The highest air temperature on 21 July 2013 was $32{ }^{\circ} \mathrm{C}$ while on 21 July 2018 , it was $27.7^{\circ} \mathrm{C}$. The chilliest temperatures in decades in parts of Australia's east coast (Sun, 2018) suggests the impact of lower temperature throughout Southeast Asia. The weather service of Australia recorded that it was the town's chilliest night in 87 years (Willoughby, 2018). Low temperatures in Australia have an influence on the formation of cold winds from the Australian continent to Asia, including to Indonesia. Thus, the result on Tmrt tends to be only in the range of $24.4{ }^{\circ} \mathrm{C}-39.1^{\circ} \mathrm{C}$, which is quite a difference when, in 2013 , the MRT reached $21.5^{\circ} \mathrm{C}$ to $48.5^{\circ} \mathrm{C}$. The gap between air temperature and globe temperature has a significant impact on the rising of MRT. In dense urban areas, with an absence of wind flow, the heat trapped within the urban structure and building surface cannot easily be swept away.

\section{Conclusion}

As a conclusion of this study, the comparison of the three urban structures and their microclimate gives an understanding that geographical location impacts initial temperature. The higher the altitude, the lower the initial air temperature. The dense urban build characterized by high building coverage, low floor area ratio, and narrow street canyon has less offering on wind flow. In any case, this urban structure not only blocks insolation but also tends to retain humidity. It, therefore, contributes to the low globe temperature and mean radiant temperature. This condition also contributes to the afternoon temperature that is higher than morning temperature.

It is found that in all studies, the noon temperature is higher than the morning temperature. More overcrowded urban structures have small differences in di- urnal temperature. This effect is more evident in dense urban structures. Gerlong Girang, with building coverage of $83-98 \%$, has a temperature gap of $4.2{ }^{\circ} \mathrm{C}$. Pasir Impun, with the less dense urban structures with building coverage of $38-82 \%$, has a temperature gap of $5{ }^{\circ} \mathrm{C}$. Linggawastu, with building coverage $96.3-100 \%$, has a temperature gap of $0.7^{\circ} \mathrm{C}$. In the tropical climatic region, the availability of urban ventilation is necessary to sweep the heat, especially within a narrow urban canyon. However, in a wide canyon, wind flow does not significantly remove the heat from the exposure of insolation. It needs shadowing to help filter the radiation then reduce the daily air temperature. In the end, the microclimate is also more or less influenced by the macroclimate. Atmospheric conditions and global climate also have a large influence on the microclimate.

\section{Acknowledgements}

The authors would like to thank Fukuda Laboratory, The University of Kitakyushu for the instrument. Ridwan, Fahmi, Hafiz, Putri, Viko and Nabila for collecting data and also the Building Science Research Team of DPTA-UPI.

\section{References}

Ahmed, K. S. (2003). Comfort in urban spaces: defining the boundaries of outdoor thermal comfort for the tropical urban environments. Energy and Buildings, 35(1), 103-110. https://doi.org/10.1016/ So378-7788(02)00085-3

Allegrini, J., Dorer, V., \& Carmeliet, J. (2015). Influence of morphologies on the microclimate in urban neighbourhoods. Journal of Wind Engineering and Industrial Aerodynamics. https://doi.org/10.1016/j. jweia.2015.03.024
Bajšanski, I. V., Milošević, D. D., \& Savić, S. M. (2015). Evaluation and improvement of outdoor thermal comfort in urban areas on extreme temperature days: Applications of automatic algorithms. Building and Environment. https://doi.org/10.1016/j. buildenv.2015.10.019

BPS Bandung. (2018). Bandung City in Figure. Bandung: BPS. Retrieved from https://bandungkota.bps. go.id/subject/151/iklim.html\#subjekViewTab3 
Chen, Y. C., Lin, T. P., \& Matzarakis, A. (2014a). Comparison of mean radiant temperature from field experiment and modelling: a case study in Freiburg, Germany. Theoretical and Applied Climatology, 118(3). https://doi.org/10.1007/s00704-013-1081-Z

Chen, Y. C., Lin, T. P., \& Matzarakis, A. (2014b). Comparison of mean radiant temperature from field experiment and modelling: a case study in Freiburg, Germany. Theoretical and Applied Climatology. https://doi.org/10.1007/s00704-013-1081-Z

Dirjen-Cipta Karya, K. Penetapan Lokasi Program KOTAKU (2016). Retrieved from http://kotaku. pu.go.id/view/6903/sk-direktur-jenderal-cipta-karya-no-11o-kpts-dc-2016-tentang-penetapan-lokasiprogram-kotaku/print

Emmanuel, R., \& Johansson, E. (2006). Influence of urban morphology and sea breeze on hot humid microclimate: The case of Colombo, Sri Lanka. Climate Research. https://doi.org/10.3354/cro30189

Epstein, Y., \& Moran, D. S. (2006). Thermal comfort and the heat stress indices. Industrial Health. https://doi.org/10.2486/indhealth.44.388

Evans, J. M., \& De Schiller, S. (1996). Application of microclimate studies in town planning: A new capital city, an existing urban district and urban river front development. In Atmospheric Environment. https://doi.org/10.1016/1352-2310(94)00138-3

Fanger, P. O., \& Toftum, J. (2002). Prediction of thermal sensation in non-air conditioned buildings in warm climates. Indoor Air.

Fanger, P.O. (1972). Thermal Comfort. McGraw-Hill Companies.

Fröhlich, D., \& Matzarakis, A. (2013). Modeling of changes in thermal bioclimate: Examples based on urban spaces in Freiburg, Germany. Theoretical and Applied Climatology, 111(3-4). https://doi. org/10.1007/s00704-012-0678-y

Gulyas, A., Unger, J., \& Matzarakis, A. (2006). Assessment of the microclimatic and human comfort conditions in a complex urban environment: Modelling and measurements. Building and Environment, 41(12), 1713-1722. https://doi.org/10.1016/j. buildenv.2005.07.001

Herrmann, J., \& Matzarakis, A. (2012). Mean radiant temperature in idealised urban canyons--examples from Freiburg, Germany. International Journal of Biometeorology, 56(1), 199-203. https://doi. org/10.1007/s00484-010-0394-1

Johansson, E., \& Emmanuel, R. (2006). The influence of urban design on outdoor thermal comfort in the hot, humid city of Colombo, Sri Lanka. International Journal of Biometeorology. https://doi. org/10.1007/s00484-006-0047-6

Karyono, T. H. (2008). Bandung Thermal Comfort Study: Assessing the Applicability of an Adaptive
Model in Indonesia. Architectural Science Review, 51(1), 60-65.

Khusyairi, J. A., \& Rabani, L. O. (2011). Kampung Perkotaan Indonesia: Kajian Historis-Antropologis terhadap Kesenjangan Sosial dan Ruang Kota. Yogyakarta: ANRC DAN NEW ALMATERA.

Lai, A., Maing, M., \& Ng, E. (2017). Observational studies of mean radiant temperature across different outdoor spaces under shaded conditions in densely built environment. Building and Environment. https://doi.org/10.1016/j.buildenv.2016.12.034

Lee, T. (2011). Atlas Density. Retrieved from http:// densityatlas.org/

Lin, T.P., Matzarakis, A., \& Hwang, R.-L. (2010). Shading effect on long-term outdoor thermal comfort. Building and Environment, 45, 213-221. Retrieved from http://download.xuebalib.com/xuebalib. com.25622.pdf

Lin, T.P. (2009). Thermal perception, adaptation and attendance in a public square in hot and humid regions. Building and Environment. https://doi. org/10.1016/j.buildenv.2009.02.004

Makaremi, N., Salleh, E., Jaafar, M. Z., \& Hoseini, A. H. G. (2012). Thermal comfort conditions of shaded outdoor spaces in hot and humid climate of Malaysia. Building and Environment. https://doi. org/10.1108/JHOM-05-2018-0133

Matzarakis, A., Rutz, F., \& Mayer, H. (2007). Modelling radiation fluxes in simple and complex environments-application of the RayMan model. International Journal of Biometeorology, 51, 12. https:// doi.org/10.1007/s00484-006-0061-8

Milošević, D. D., Bajšanski, I. V., \& Savić, S. M. (2017). Influence of changing trees locations on thermal comfort on street parking lot and footways. Urban Forestry and Urban Greening. https://doi. org/10.1016/j.ufug.2017.03.011

Milošević, D. D., Savić, S. M., Marković, V., Arsenović, D., \& Šećerov, I. (2016). Outdoor human thermal comfort in local climate zones of Novi Sad (Serbia) during heat wave period. Hungarian Geographical Bulletin. https://doi.org/10.15201/hungeobull.65.2.4

Moonen, P., Defraeye, T., Dorer, V., Blocken, B., \& Carmeliet, J. (2012). Urban Physics: Effect of the micro-climate on comfort, health and energy demand. Frontiers of Architectural Research. https:// doi.org/10.1016/j.foar.2012.05.002

Ongoma, V., Muange, P. K., \& Shilenje, Z. W. (2016). Potential effects of urbanization on urban thermal comfort, a case study of Nairobi city, Kenya: A review. Geographica Pannonica. https://doi. org/10.5937/GeoPan1601019O

Paramita, B., \& Fukuda, H. (2014a). Heat intensity of urban built environment in hot humid climate re- 
gion. American Journal of Environmental Sciences. https://doi.org/10.3844/ajessp.2014.210.218

Paramita, B., \& Fukuda, H. (2014b). Public housing in bandung an assessment and approaches through Urban physics. Advanced Materials Research, 935. https://doi.org/10.4028/www.scientific. net/AMR. 935.273

Paramita, B., \& Fukuda, H. (2018). Urban Microclimate Prognostic Model in a Hot-Humid Climate Region. Journal of Advanced Research in Dynamical \& Control Systems, 10(2).

Pemkot-Bandung. SK Walikota Bandung No. 648/ Kep.286- Distarcip/2015 (2015).

Saehoon, K., \& Youngryel, R. (2015). Describing the spatial patterns of heat vulnerability from urban design perspectives. International Journal of Sustainable Development \& World Ecology, 22(3), 189200.

Shashua-Bar, L., Hoffman, M. E., \& Tzamir, Y. (2006). Integrated thermal effects of generic built forms and vegetation on the UCL microclimate. Building and Environment. https://doi.org/10.1016/j.buildenv.2005.01.032
Singapurastories. (2005). From 'Kampong' to 'Compound': Retracing the forgotten connections.

Sun, H. (2018). RECORD COLD IN AUSTRALIA. Retrieved from https://www.heraldsun.com.au/blogs/ andrew-bolt/record-cold-in-australia/news-story/6 545967e12ba597ca 4 fgdeg $97 \mathrm{fecd} 788 \mathrm{c}$

Tajudeen, I. bin. (2005). Reading the Traditional City in Maritime Southeast Asia: Reconstructing the 19th century Port Town at Gelam-Rochor-Kallang, Singapore. Journal of Southeast Asian Architecture, $8,1-25$.

Tan, C. L., Wong, N. H., \& Jusuf, S. K. (2013). Outdoor mean radiant temperature estimation in the tropical urban environment. Building and Environment, $64,118-129$.

Willoughby, J. (2018). Brrrr: Australia's bitterly cold snap to continue, experts warn. Retrieved from $\underline{h t-}$ ps://thenewdaily.com.au/news/national/2018/o7/15/ australia-cold-weather/

Yang, W., Wong, N. H., \& Jusuf, S. K. (2013). Thermal comfort in outdoor urban spaces in Singapore. Building and Environment, 59. https://doi. org/10.1016/j.buildenv.2012.09.008 